\title{
Enhancement of Methane Oxidation at the Cermet Anode Consisting of Nickel-Cobalt and Samaria-Doped Ceria in Solid Oxide Fuel Cells
}

\author{
Kazunori Sato*, Hiromasa Tsuchiya, Jirachaya Ayawanna and Teoh Wahtzu \\ Department of Environmental Engineering, Nagaoka University of Technology, \\ Nagaoka, Niigata 940-2188, Japan
}

(Received March 2, 2015; accepted July 13, 2015)

Key words: microstructure, solid solution, cell performance, overpotential, methane oxidation

The partial substitution of $\mathrm{Co}$ atoms for $\mathrm{Ni}$ atoms in the Ni-based cermet anode resulted in a decrease in the anodic overvoltage and interfacial resistance between the anode and electrolyte. This effect has been confirmed for single solid oxide fuel cells using a samaria-doped ceria (SDC) electrolyte. The results of electrochemical measurements and a product analysis by gas chromatography revealed that the direct oxidation of $\mathrm{CH}_{4}$ is enhanced by the modification of the microstructure in the cermet anode, the effect of which is combined with a sufficient oxide ion supply through the electrolyte.

\section{Introduction}

Solid oxide fuel cells (SOFCs) have recently attracted much attention as a promising on-site power generation system owing to their high efficiency. The most attractive advantage of SOFCs is their adaptability to the existing infrastructure of the municipal gas power supply system. In particular, the electrode activity of the SOFC anode is important for its high performance. ${ }^{(1-5)}$ The nickel and yttria-stabilized zirconia (NiYSZ) cermet anode is most commonly used for the generation of a $\mathrm{H}_{2}$-rich gas by the steam reforming of $\mathrm{CH}_{4}$. This cermet anode is used as a porous layer in order to provide reaction paths at the interface between nickel particles and the YSZ electrolyte. However, the Ni-YSZ cermet anode generally shows a low activity for the direct electrochemical oxidation of $\mathrm{CH}_{4}$. The development of a proper metal or alloy catalyst with the combination of a high-oxide-ion conductor is required for the electrochemical oxidation of hydrocarbon fuels.

We therefore investigated the electrochemical performance of an anode consisting of Ni-Co solid-solution alloy particles combined with a samaria-doped ceria (SDC) electrolyte. The anodic polarization resistance of the $\mathrm{Ni}_{1-X} \mathrm{Co}_{X}-\mathrm{SDC}$ anode was

${ }^{*}$ Corresponding author: e-mail: sato@analysis.nagaokaut.ac.jp 
investigated for $\mathrm{CH}_{4}$. The microstructure of these cermet anodes was caracterized to reveal the origin of the enhancement effect on the electrochemical oxidation of $\mathrm{CH}_{4}$.

\section{Materials and Methods}

$\mathrm{A} \mathrm{Ni}_{1-X} \mathrm{Co}_{X} \mathrm{O}$ solid solution was prepared by heating a mixture of reagent-grade $\mathrm{NiO}$ and $\mathrm{Co}_{3} \mathrm{O}_{4}$ powders in an alumina crucible at $1273 \mathrm{~K}$ for $10 \mathrm{~h}$ in air. Phase identification of the prepared powders was made by X-ray diffraction (XRD). Pulverized $\mathrm{Ni}_{1-X} \mathrm{Co}_{X} \mathrm{O}$ powders were mixed with the $\mathrm{Ce}_{0.8} \mathrm{Sm}_{0.2} \mathrm{O}_{1.9}$ (SDC, NexTech) powder at a ratio of 40 mass $\%$ to form a slurry in glycerol. The slurry was painted as the anode on one face of the electrolyte. An SDC electrolyte disk (Shinko Electric Industries) $15 \mathrm{~mm}$ in diameter and $0.3 \mathrm{~mm}$ thick and an $\mathrm{ScSZ}\left(10 \mathrm{~mol} \% \mathrm{Sc}_{2} \mathrm{O}_{3}-1 \mathrm{~mol} \% \mathrm{CeO}_{2}-\mathrm{ZrO}_{2}\right.$, Daiichi Kigenso Kagaku Kogyo) disk $15 \mathrm{~mm}$ in diameter and $0.2 \mathrm{~mm}$ thick were used as the electrolytes. The painted disks were heated at $1573 \mathrm{~K}$ for $5 \mathrm{~h}$. $\left(\mathrm{La}_{0.85} \mathrm{Sr}_{0.15}\right)_{0.9} \mathrm{Mn}_{0.1} \mathrm{O}_{3}$ (LSM) powder and $\mathrm{Sm}_{0.5} \mathrm{Sr}_{0.5} \mathrm{Co}_{3}$ (SSC) powder were used as the cathode for the ScSZ and SDC electrolyte disks, respectively. Cathode powders were mixed with glycerol to form a slurry. This slurry was painted on the other face of the electrolyte disk, and the disk was heated at $1473 \mathrm{~K}$ for $4 \mathrm{~h}$. The anode was reduced in a $\mathrm{H}_{2}$ atmosphere at $973 \mathrm{~K}$ to obtain a Ni-based SDC cermet before the cell measurements were recorded.

The fuel cell test assembly with the two-electrode configuration was used to evaluate the current-voltage $(I-V)$ characteristics. Oxygen gas was supplied to the cathode at a flow rate of $2 \times 10^{-5} \mathrm{~m}^{3} / \mathrm{min}$. Methane gas was also used as the fuel. The $\mathrm{CH}_{4}$ gas diluted with $\mathrm{He}$ in a volume ratio of 1:9 was used as the fuel gas at a total flow rate of 2 $\times 10^{-5} \mathrm{~m}^{3} / \mathrm{min}$. The $I-V$ curves of the cells were measured at $923-1023 \mathrm{~K}$. The anodic overvoltage was measured by the current interruption method. The outlet gas from the anode was analyzed by gas chromatography (Shimadzu-GC8A). Impedance spectra were recorded with an impedance meter (Yokogawa WT1600).

\section{Results and Discussion}

Figure 1 shows the $I-V$ and current-power curves $(I-P)$ for a cell using a NiSDC cermet (cell 1) and one using a $\mathrm{Ni}_{0.5} \mathrm{Co}_{0.5}$-SDC cermet (cell 2) as the anode, both combined with the ScSZ electrolyte. The maximum power density for cell 2 was $89 \mathrm{~mW}$ $\mathrm{cm}^{-2}$, which is higher than that for cell $1\left(70 \mathrm{~mA} \mathrm{~cm}{ }^{-2}\right)$ when $\mathrm{CH}_{4}$ was supplied as the fuel.

Figure 2 shows the voltage drop across the anode and cathode with respect to the reference electrode for the Ni-SDC anode (cell 1) and the $\mathrm{Ni}_{0.5} \mathrm{Co}_{0.5}-\mathrm{SDC}$ anode (cell 2) for $\mathrm{CH}_{4}$. The increase in the anodic overvoltage with the discharge current is more evident for cell 1 than for cell 2 with $\mathrm{CH}_{4}$ feeding.

Figure 3 shows SEM images of the interfacial region between the cermet anode and the electrolyte after cell testing. A comparison of the microstructures between cell 1 and cell 2 shows a significant increase in the grain size of the cermet anode in cell 2. Figure 4 shows $\mathrm{SEM}$ images of the mixtures of $\mathrm{NiO}$ and $\mathrm{Co}_{3} \mathrm{O}_{4}$ starting powders at different ratios after heating at $1273 \mathrm{~K}$ for $10 \mathrm{~h}$. Increasing the ratio of Co to Ni resulted in a grain growth in $\mathrm{Ni}_{1-X} \mathrm{Co}_{X} \mathrm{O}$, which is not expected considering the melting points of $\mathrm{NiO}(2257 \mathrm{~K})$ and $\mathrm{CoO}(2206 \mathrm{~K})$. Since $\mathrm{Co}_{3} \mathrm{O}_{4}$ decomposes into $\mathrm{CoO}$ at $1168 \mathrm{~K}$, the phase transformation of $\mathrm{Co}_{3} \mathrm{O}_{4}$ to $\mathrm{CoO}$ can affect the grain growth during the solid- 

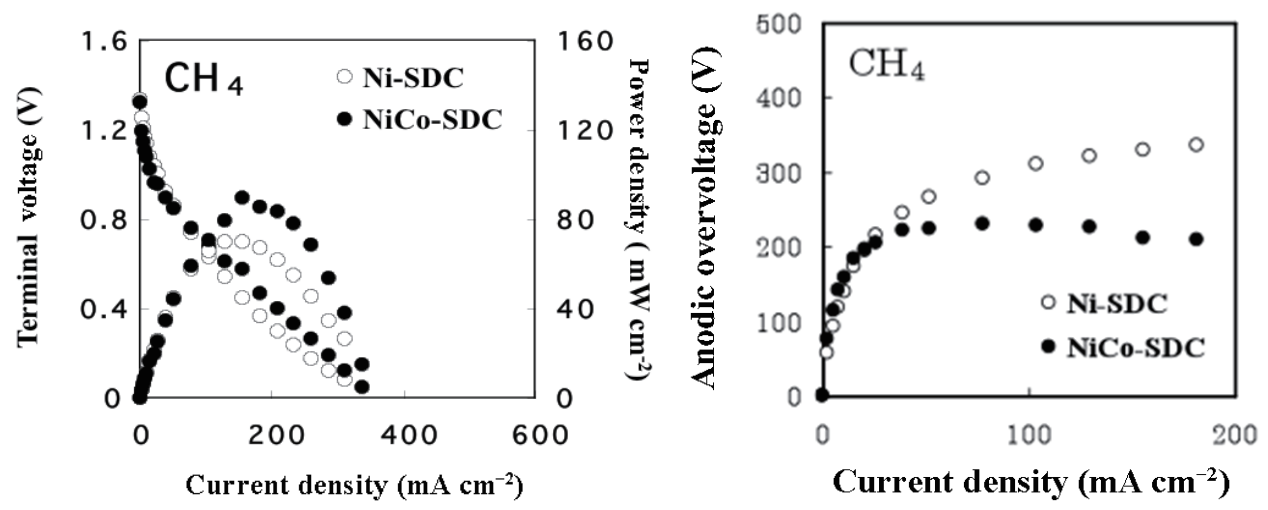

Fig. 1 (left). $I-V$ and $I-P$ curves for cell 1 and cell 2 at $1023 \mathrm{~K}$.

Fig. 2 (right). Anodic overvoltages for cell 1 and cell 2 at $1023 \mathrm{~K}$.

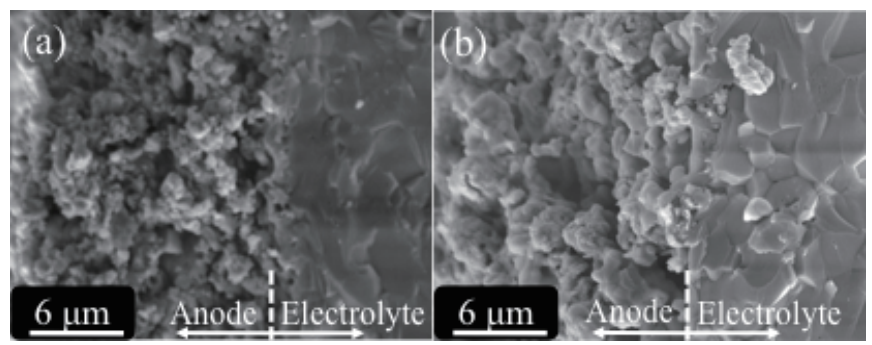

Fig. 3. Microstructures of the interfacial region of (a) cell 1 and (b) cell 2.

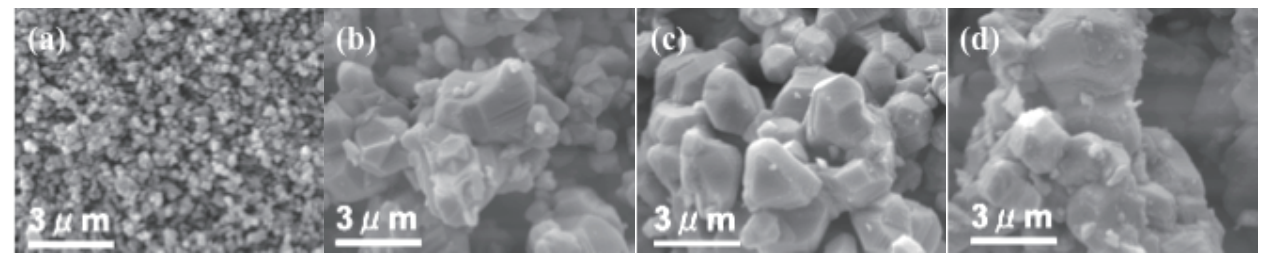

Fig. 4. Microstrucures of the $\mathrm{NiO}-\mathrm{Co}_{3} \mathrm{O}_{4}$ mixed powders heated at $1273 \mathrm{~K}$ for $10 \mathrm{~h}$, which form the $\mathrm{Ni}_{1-X} \mathrm{Co}_{X} \mathrm{O}$ solid solution particles with $X=$ (a) 0 , (b) 0.25 , (c) 0.5 , and (d) 0.75 .

state reaction between $\mathrm{NiO}$ and $\mathrm{CoO}$. Furthermore, $\mathrm{Co}_{3} \mathrm{O}_{4}$ was found to be a sintering promoter of SDC at $1773 \mathrm{~K} .{ }^{(6)}$ The ionic radius of $\mathrm{Co}^{2+}$ ions $(78 \mathrm{pm})$ is much smaller than that of $\mathrm{Ce}^{4+}$ ions $(101 \mathrm{pm})$ in the SDC lattice. This difference most likely causes the enhancement of the grain boundary mobility owing to a large distortion in the surrounding lattice that facilitates the defect migration in ceria. ${ }^{(6)}$ Figure 4 also reveals that the grain size was almost uniform in the $\mathrm{Ni}_{0.5} \mathrm{Co}_{0.5} \mathrm{O}$. These results suggest that the decrease in the anodic overvoltage for the $\mathrm{Ni}_{0.5} \mathrm{Co}_{0.5} \mathrm{SDC}$ anode (cell 2) was caused by a 
decrease in the resistance to fuel gas diffusion to reaction sites at the interface between the electrolyte and the anode.

Figure 5 shows the production rates of $\mathrm{H}_{2}, \mathrm{CO}$, and $\mathrm{CO}_{2}$ with the current density at $973 \mathrm{~K}$ in the outlet gas from the $\mathrm{Ni}_{0.5} \mathrm{Co}_{0.5}$ - $\mathrm{SDC}$ cermet anode of a cell using SDC as the electrolyte (cell 3). The formation of $\mathrm{H}_{2}$ or $\mathrm{CO}$ was detected at the open-circuit voltage $(\mathrm{OCV})$, that is, $0 \mathrm{~mA} \mathrm{~cm}{ }^{-2}$. However, we found that the production of $\mathrm{H}_{2}, \mathrm{CO}$, and $\mathrm{CO}_{2}$ was not detected at the open-circuit voltage when a zirconia-based electrolyte was used.(7)

The direct oxidation of methane at the SOFC anode is expressed as

$$
\begin{gathered}
\mathrm{CH}_{4}+4 \mathrm{O}^{2-} \rightarrow \mathrm{CO}_{2}+2 \mathrm{H}_{2} \mathrm{O}+8 \mathrm{e}^{-}, \\
\mathrm{CH}_{4}+\mathrm{O}^{2-} \rightarrow \mathrm{CO}+2 \mathrm{H}_{2}+2 \mathrm{e}^{-} .
\end{gathered}
$$

Molecules of $\mathrm{CH}_{4}$ adsorb at active sites on the metal surface of the anode, and they can decompose into the elements at temperatures lower than the thermodynamic decomposition temperature of $1058 \mathrm{~K} .{ }^{(8)}$ The $\mathrm{CH}_{4}$ decomposition depends on the chemical bond formed with the metal surface and other nearby adsorbed species. The decomposition of $\mathrm{CH}_{4}$ into carbon and hydrogen can lead to reactions with oxide ions transported through the electrolyte. Nickel has a strong affinity for $\mathrm{CH}_{4}$ and $\mathrm{CO}$ molecules, which results in coking and/or a $\mathrm{CO}$ poisoning effect on the metal catalyst. The addition of $\mathrm{Ni}$ atoms to $\mathrm{Co}$ atoms can impede this effect during the electrochemical oxidation of $\mathrm{CH}_{4}$ at the cermet anode. Hydrogen is electrochemically converted to $\mathrm{H}_{2} \mathrm{O}$ much faster than $\mathrm{CO}$ to $\mathrm{CO}_{2}$ at low oxygen potentials. Although the production rate of $\mathrm{H}_{2} \mathrm{O}$ could not be measured, the stoichiometric ratio of $\mathrm{H}_{2}$ to $\mathrm{CO}$, particularly for dry $\mathrm{CH}_{4}$ feeding, implied the partial oxidation of $\mathrm{CH}_{4}$ with the oxide ions. Figure 5 shows the partial oxidation of $\mathrm{CH}_{4}$ under $\mathrm{OCV}$ conditions. This result indicates that the oxide-ion supply can occur through the electrolyte. This is probably specific to the electrochemical properties of SDC electrolytes. Ceria-based electrolytes show electronic conductivity at low oxygen partial pressures, which leads to an electronic current flow through the electrolyte of a cell

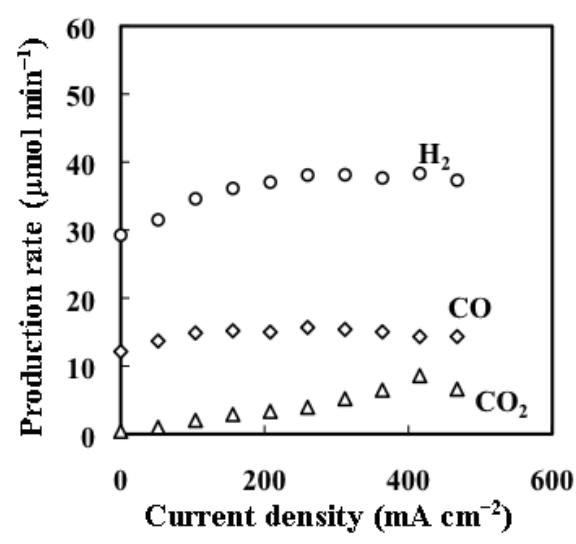

Fig. 5. Production rates of $\mathrm{H}_{2}, \mathrm{CO}$, and $\mathrm{CO}_{2}$ formed by the electrochemical oxidation of $\mathrm{CH}_{4}$ at $973 \mathrm{~K}$ for cell 3. 
even at $0 \mathrm{~mA} \mathrm{~cm}{ }^{-2}$.(9) When a cell is constructed with a $\mathrm{CeO}_{2}$-based electrolyte, the $\mathrm{CeO}_{2}$ electrolyte is partially reduced at the anode side. ${ }^{(10)}$ The SDC electrolyte surface of cell 3 exposed to $\mathrm{CH}_{4}$ produced $\mathrm{H}_{2}$ and $\mathrm{CO}$ with the consumption of the lattice oxygen at low current densities according to eq. (2). The mixed ionic-electronic conduction in SDC can cause a short-circuit current flow at low current densities, which contributes to the electrochemical stability of cell 3 due to a concurrent supply of oxide ions and electrons to the anode side of the SDC electrolyte. The production rates of $\mathrm{H}_{2}$ and $\mathrm{CO}$ showed a gradual decrease with an increase in that of $\mathrm{CO}_{2}$ above approximately $200 \mathrm{~mA} \mathrm{~cm}{ }^{-2}$. At higher current densities, $\mathrm{CO}_{2}$ is more favorable as a product than $\mathrm{H}_{2}$ and $\mathrm{CO}$ according to eq. (1); oxide ion conduction is more dominant at higher current densities. ${ }^{(9)}$ It seems that the reduction of $\mathrm{Ce}^{4+}$ ions to $\mathrm{Ce}^{3+}$ ions, which is caused by the adsorption of methane onto the surface of a $\mathrm{Sm}_{2} \mathrm{O}_{3}$-doped cerium oxide and the association with oxygen surface species in the oxide, enhances the electrochemical oxidation of methane. ${ }^{(11)}$

Our results show that the electrochemical oxidation and activation of methane can be enhanced by suitable alloying in the metal catalysts of the cermet anode. The formation of surface active sites on the nickel-based catalyst plays an important role in the electrochemical oxidation of adsorbed $\mathrm{CH}_{4}$ molecules; the partial oxidation of $\mathrm{CH}_{4}$ takes place at these active surface sites, and they contribute to the production of $\mathrm{H}_{2}, \mathrm{CO}$, and $\mathrm{CO}_{2}$ depending on the amount of oxide ions supplied through the electrolyte. Molecules of $\mathrm{CO}$ adsorb strongly to the nickel surface owing to the back donation of electrons into the vacant orbital from the $3 \mathrm{~d}$ electrons of nickel. This strong adsorption of $\mathrm{CO}$ molecules retards the further partial oxidation of $\mathrm{CH}_{4}$ molecules on the nickel surface. Replacement of Co atoms with $\mathrm{Ni}$ atoms can weaken the adsorption of $\mathrm{CO}$ molecules since the electron density of the $3 \mathrm{~d}$ orbitals of Co atoms is lower than that of $\mathrm{Ni}$ atoms.

Figure 6 shows the relationship of the cell stability for cell 3 between the maximum power density and the impedance spectra as a function of time for $\mathrm{CH}_{4}$ feeding. The anodic polarization resistance for the electrochemical oxidation of $\mathrm{CH}_{4}$ did not appreciably increase after $20 \mathrm{~h}$, which corresponds to the stability of the maximum power density. This result indicates that the cell using the $\mathrm{Ni}_{0.5} \mathrm{Co}_{0.5}-\mathrm{SDC}$ anode combined with the SDC electrolyte showed good performance for the direct oxidation of $\mathrm{CH}_{4}$.

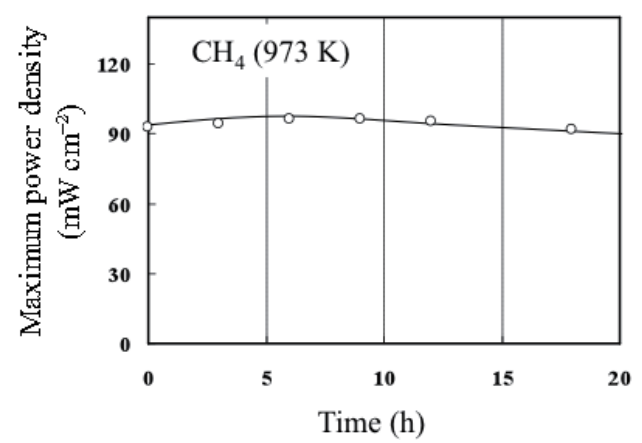

(a)

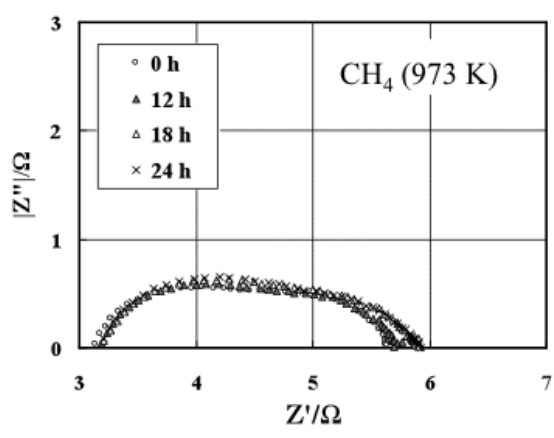

(b)

Fig. 6. (a) Maximum power density of cell 3 as a function of time and (b) impedance spectra of cell 2 corresponding to the times shown in (a). 


\section{Conclusions}

The $\mathrm{Ni}_{1-X} \mathrm{Co}_{X}$-SDC cermet anode showed an increase in cell performance at a Co content of 0.5. A decrease in the anodic overvoltage and interfacial resistance contributed to the enhancement of cell performance. Grain growth of $\mathrm{Ni}_{1-X} \mathrm{Co}_{X}$ particles and SDC particles became prominent with increasing amounts of the Co substitution in the binary Ni-Co alloy system in the cermet anode. The enhancement of the cell performance for the direct oxidation of $\mathrm{CH}_{4}$ is most likely caused by the weak adsorption of $\mathrm{CO}$ molecules, which is a product of the partial oxidation of $\mathrm{CH}_{4}$ with the $\mathrm{O}^{2-}$ ions transported through the electrolyte, on the surface of $\mathrm{Ni}_{1-X} \mathrm{Co}_{X}$ particles and the decrease in the interfacial resistance.

\section{Acknowledgements}

This work was supported by a Grant-in-Aid for Scientific Research (B) (\#24360304) from the Ministry of Education, Culture, Sports, Science and Technology. The SDC electrolyte disks were generously supplied by Shinko Electric Industries Co., Ltd.

\section{References}

1 A. McEvoy: High Temperature Solid Oxide Fuel Cells, eds. S. C. Singhal and K. Kendall (Elsevier, UK, 2003) pp. 149-169.

2 A. Hammou and J. Guindet: The CRC Handbook of Solid State Electrochemistry, eds. P. J. Gellings and H. J. M. Bouwmeester (CRC Press, Boca Raton, 1997) pp. 419-422.

3 H. Uchida, T. Osuga and M. Watanabe: J. Electrochem. Soc. 146 (1999) 1677.

4 M. Watanabe, H. Uchida and M. Yoshida: J. Electrochem. Soc. 144 (1997) 1739.

5 T. Setoguchi, K. Okamoto, K. Eguchi and H. Arai: J. Electrochem. Soc. 139 (1992) 2875.

6 H. Yoshida and T. Inagaki: J. Alloys Compds. 408/412 (2006) 632.

7 K. Sato and K. Ogasa: ITE Lett. 7 (2006) 39.

8 W. A. Bone and H. F. Coward: J. Chem. Soc. 93 (1908) 93.

9 M. Gödickemeier and L. J. Gauckler: J. Electrochem. Soc. 145 (1998) 414.

10 H. Yahiro, Y. Eguchi, K. Eguchi and H. Arai: J. Appl. Electrochem. 18 (1988) 527.

11 B. C. H. Steele: Nature 400 (1999) 619. 